\title{
A modern-day miracle of the loaves and fishes?
}

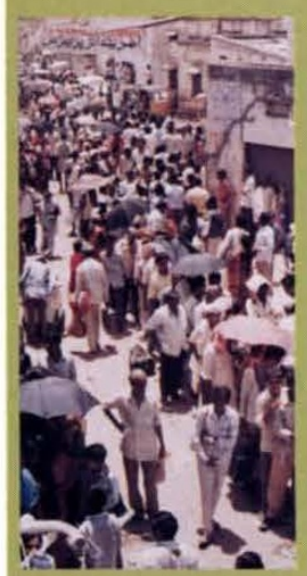

Western science may dismiss it as blind faith or plain superstition. Yet every June 7 for the past 150 years thousands of Indians and foreigners alike flock to the south Indian city of Hyderabad to receive "fish medicine," that is, a live fish stuffed with a secret herbal preparation thrust down their throats. This year an estimated half a million people swallowed the unorthodox therapy on "Mirgasira Karti," an auspicious day in the Hindu calendar. The medical minnows, which are supposed to cure the bronchial asthma that afflicts 7 out of every 100 Indians, are provided free-of-charge by a family that claims to have inherited the formula from descendants of Charaka, one of the founders of the 2,500-year-old system of medicine called Ayurveda.

"Don't ask me if it works," says Harinath Goud, eldest of five brothers who are now carrying on the family tradition. "Ask those who ate the fish." One of those is Subir Kumar Mazumdar, a physician who runs a clinic in Delhi and himself an asthma victim. "I was on medication, including injectable steroids, for 365 days a year for ten years and considered myself to be a hopeless case," he says. "Then I went to Hyderabad in 1992 to try the fish as a last resort. Now I am totally off medication and even attacks of sneezing have stopped." Mazumdar has no scientific explanation, but he believes the fish medicine is a "miracle" for asthma-sufferers.

The god-fearing Goud family, whose main occupation is rice cultivation, neither know about how their medicated fish works, nor care about what scientists think of it. "We are carrying on what our great grandfather, Veeranna Goud, was ordained to do by a holy man in 1845 ," says Goud.

The Gouds make no money from their fish therapy, as they charge no fee for the service: indeed, they spend about US\$1,000 of their own each year, relying on the help of some 250 family members and 600 volunteers who make the annual event possible. In addition, poor people who make the pilgrimage to Hyderabad also get free food.

And make the pilgrimage they do. "Anyone doubting the efficacy of the medication should just take a look at the crowd," says Goud, who counts several thousands of foreigners among his annual "patients." According to a Hyderabad city official, on that day all roads lead to the Gouds' ancestral home on a narrow lane where "people start lining up the previous night." The Gouds have the support of the state government, which supplies free water and electricity, as well as police crowd control.

The fish used belong to the species Channa punctatus and Channa orientalis, which measure two to three inches in length. The homemade herbal medication is put inside the mouth of the fingerlings before being pushed into patients' throat. The herbed fish is slippery, so swallowing it poses little problem. "You can feel the fish flapping inside your stomach for several minutes," said
Uday Shankar, one of the recipients. "Then it is all quiet." Recipients are then sent home with two doses of the herbal mix (no fish) to be taken in 15 days. They are also required to follow a restricted diet for 45 days, and come back again the next two years for the fish. According to Harinath Goud, "There is a complete cure if the course is continued for three conisecutive years."

Not many Indian doctors are convinced of the claims made by the Gouds and their patients. "Asthma, which is hereditary, is controllable but not curable," says Rohit Sobti, director of the privately owned National Chest Institute in Delhi. "I know people who felt better after taking fish but eventually came back to me." Sobti believes that the feeling of relief experienced after taking the fish medicine is due to a combination of placebo effect and faith healing. "It is like going to temple," he says. "You thank God if your problem is solved, but don't blame Him if your prayers were not answered."

However, a few doctors are not so dismissive of the fish medicine's possible efficacy. Ashok Kaushik, director of the National Asthma Research Centre in Delhi, claims that observations he has made over the last 20 years show that fish medicine benefits those with "high eosinophil counts and whose asthma is of recent origin," yet he also says he has about 200 "chronic" asthma patients who did not find the fish useful.

Ajit Vigg, head of respiratory medicine in Apollo hospital in Hyderabad, speaks for many both in India and in Western medicine:

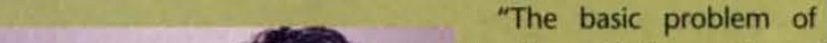
asthma is inflammation of bronchial tubes," he says. "There is no scientific evidence that fish therapy helps in reversing this." But strict scientific evidence is unlikely to come any time soon, because the government is not keen to launch a clinical trial. One reason is a lack of funds: "We do not have the money to verify every claim, and there are several such claims," says S.C. Chaturvedi, secretary to the newly created Department of Indian Medicine. Another reason is more pragmatic: "People go for fish medicine out of faith, which cannot be shaken by any scientific study, whatever its outcome," says G.V. Satyavati, director general of the Indian Council of Medical Research (ICMR). Avtar Singh Paintal, former director of the Patel Chest Institute in New Delhi agrees: "If people think they are getting benefit from fish therapy, why waste money on a clinical trial?"

Satyavati points out that ICMR cannot conduct a trial even if it wanted to, because "it is unethical to ask people to swallow a medicine without knowing its contents." The Goud brothers, who have kept the formula a secret even from their wives, have resisted pressure to disclose it to drug companies. Says Goud: "We don't want this knowledge to be commercialized. Period."

K.S. JAYARAMAN New Delhi, India 